\title{
Management of root-knot nematode Meloidogyne incognita of eggplant using some growth-promoting rhizobacteria and chitosan under greenhouse conditions
}

\author{
Usama Samy Elkelany*, Nehal Samy El-Mougy and Mokhtar Mohamed Abdel-Kader
}

\begin{abstract}
Background: Eggplant (Solanum melongena) is one of the most popular vegetable crops in Egypt. It is affected by a wide range of pests; prominent among them is root-knot nematode (RKN) Meloidogyne spp. which constitutes a major group of plant-parasitic nematodes causing great economic losses worldwide especially in Egypt.

Main body: The present investigation was performed under greenhouse conditions to evaluate the potentials of 3 growth-promoting bacteria, Azospirilum brasilense, Azotobacter chroococcum, and Bacillus subtilis, as well as chitosan for the control of the nematode Meloidogyne incognita causes root-knot disease of eggplant cv. Baladi. All treatments reduced $(p \leq 0.05)$ the nematode population in soil and roots as well as enhanced the plant growth parameters of eggplant remarkably than the control. The applied treatments varied in their efficacy against the plant nematode infection in correspondence to the time of application. The recorded results demonstrated that maximum reduction in $\mathrm{J}_{2}$ in soil, egg mass/root, and eggs/egg masses were obtained by treating the soil with Bacillus subtilis followed by Azospirilum brasilense and Azotobacter chroococcum. Also, chitosan resulted in high reduction in root galls compared to control treatment.

Conclusion: The use of plant growth-promoting rhizobacteria, Azospirilum brasilense, Azotobacter chroococcum, Bacillus subtilis, and chitosan achieved efficient control to Meloidogyne incognita and consequently increase eggplant growth parameters under greenhouse conditions. The present results suggested introducing such rhizobacteria in integrated nematode management program.
\end{abstract}

Keywords: Biocontrol, Azospirilum brasilense, Azotobacter chroococcum, Bacillus subtilis, Chitosan, Eggplant, Meloidogyne incognita, Root-knot

\section{Background}

Eggplant (Solanum melongena) is one of the most popular vegetable crops of tropical and subtropical countries. Eggplant is affected by a wide range of pests; prominent among them is the root-knot nematode (RKN) Meloidogyne spp. which constitutes a major group of plantparasitic nematodes causing economic losses. Infected plants showed stunting, chlorosis, reduction of water

\footnotetext{
* Correspondence: usamasamy_nrc@yahoo.com

Department of Plant Pathology, National Research Centre, Giza 12622, Egypt
}

uptake, nutrients transport lead to yield reduction (Oka et al. 2000). Using synthetic nematicides is the best method of managing this pest (Talavera et al. 2012), but the overuse of these agrochemicals is associated with being hazardous to human health, livestock, plants, and the beneficial soil fauna. This situation imposes a challenge to innovate effective, safe, and cheap alternative control strategies. In this concern, growth-promoting bacteria (rizobacteria) and chitosan were reported to be effective and safe for controlling plant-parasitic nematodes.
Springer Open
(-) The Author(s). 2020 Open Access This article is licensed under a Creative Commons Attribution 4.0 International License which permits use, sharing, adaptation, distribution and reproduction in any medium or format, as long as you give appropriate credit to the original author(s) and the source, provide a link to the Creative Commons licence, and indicate if changes were made. The images or other third party material in this article are included in the article's Creative Commons licence, unless indicated otherwise in a credit line to the material. If material is not included in the article's Creative Commons licence and your intended use is not permitted by statutory regulation or exceeds the permitted use, you will need to obtain permission directly from the copyright holder. To view a copy of this licence, visit http://creativecommons.org/licenses/by/4.0/. 
It was reported that beneficial bacteria can compete with nematodes through different types of mechanisms: production of bioactive substances (toxins; metabolites such as protease, chitinase, glucanase, antibiotics, and antimicrobial peptides) which affect directly nematode's egg hatching and nematode mobility, interference with plant nematode recognition, synthesis of enzymes that can modulate plant hormone levels and indirectly by alteration of the root exudates, which make roots less attractive to nematodes and induced systemic resistance against nematode invasion. Furthermore, the bacteria can improve plant growth and productivity through production of growth hormones (IAA, gibberellins, and auxins) or converting unavailable minerals and organic compounds into available forms to plants (Khan et al. 2008). On the other hand, chitosan is a deacetylated and soluble form of chitin elicit plant defenses by increasing the biosynthesis of phytoalexins, callose, lignin, and other phenolic compounds resulted in inducing local and systemic resistance against root-knot nematode (RKN) Meloidogyne spp. also is biodegradable and environmentally safe (El-Hadrami et al. 2010). Broadly, because of the activities of such agents which are influenced by the soil biota and host plant factors, it is important to estimate them against the target nematode on the certain crop grown in native soil conditions in order to identify their effectivity.

The present work was carried out to evaluate the suppression effect of 3 rhizobacteria as well as chitosan against M. incognita infection and its population of eggplant cv. Baladi. under greenhouse conditions.

\section{Main text}

Nematicidal potential of 3 rhizobacteria, viz. Azospirilum brasilense, Azotobacter chroococcum, and Bacillus subtilis in addition to chitosan against the root-knot nematode (RKN); Meloidogyne incognita on eggplant $\mathrm{cv}$. Baladi was evaluated. Bacterial source was the Plant Pathology Dept., National Research Centre, Giza, Egypt, where the experiment was conducted in its greenhouse. All the bacterial strains were used as cell suspension at concentration of $1 \times 10^{8} \mathrm{cell} / \mathrm{ml}$ after Abdel-Kader et al. (2012). Meanwhile, chitosan was used as water solution at concentration of 2\% (El-Sayed and Mahdy 2014-15).

\section{Rearing and identification of nematodes}

Plastic pots (25-cm diameter) were filled with $2 \mathrm{~kg}$ loamy clay natural soil which was left for more than 6 months without cultivation. For nematode inoculum, pure culture of $M$. incognita was established from a single egg mass maintained on tomato plants under greenhouse conditions and the nematode identification was undertaken, using the perineal patterns technique (Taylor and Sasser 1978).
Nematode eggs were extracted by macerating infected tomato roots in $0.5 \%(\mathrm{v} / \mathrm{v}) \mathrm{NaClO}$ as described by Hussey and Barker (1973).

\section{Greenhouse experiment}

Treatments were designated for each tested agent as follows: (1) 3 days before nematode inoculation, (2) simultaneously with nematode inoculation, and (3) simultaneously and 1 month after the first treatment. Each pot transplanted with 1-month-old eggplant seedling in the center and received $5 \mathrm{ml}$ from each agent's preparation and $2000 \mathrm{M}$. incognita eggs around eggplant root zone. All treatments were replicated 5 times and the untreated plants were served as control. All pots were arranged in a complete randomized design on the bench of the greenhouse watered daily and fertilized with NPK as recommended.

\section{Data recorded}

Sixty days after nematode inoculum plants were uprooted and root galls were counted as mean for each treatment. The roots were stained for $15 \mathrm{~min}$ in an aqueous solution of Phloxine B stain $(0.15 \mathrm{~g} / \mathrm{l}$ water), then washed with running tap water to remove residual stain and the egg mass was determined (Holbrook et al. 1983). Soils at each treatment were thoroughly mixed to represent the whole sample and the nematodes were extracted using sieving and decanting technique from an aliquot of $250 \mathrm{~g}$ soil. Extracted second-stage juveniles $\left(\mathrm{J}_{2} \mathrm{~s}\right)$ were counted in $1 \mathrm{ml}$ suspension using a counting slide under light microscope and repeated 5 times then calculated as means. Eggs/egg mass was recorded by detaching 10 egg masses from infected roots of each treatment, using a needle and exposed to sodium hypochlorite (2\%) for $3 \mathrm{~min}$ and released eggs were counted.

Eggplant growth parameters were recorded as root and shoot lengths, fresh and dry shoot weights, and numbers of leaves/plant.

Nematode reduction $\%=[\mathrm{C} 1-\mathrm{C} 2 / \mathrm{C} 1] \times 100$

where $\mathrm{C} 1=$ No. of live nematodes juveniles in control and $\mathrm{C} 2=$ No. of live nematodes juveniles in treatments

Increase \% = Eggplant growth parameters in Treatment - Eggplant growth parameters in control $\div$ Eggplant growth parameters in control $\times 100$

\section{Statistical analysis}

Collected data were subjected to the analysis of variance test (ANOVA) as complete randomized design for greenhouse experiment using (Assistant) program and mean values were compared using Duncan (1955) multiple range test. 


\section{Results and discussion}

Effect of the different treatments on root-knot nematode population

Data presented in Tables 1 and 2 and illustrated in Figs. 1 and 2 revealed the significant $(p \leq 0.05)$ suppression effects of the applied agents $A$. brasilense, A. chroococcum, $B$. subtilis, and chitosan on $M$. incognita population in terms of number of $\mathrm{J}_{2} \mathrm{~S}$ in soil and roots, galls and egg mass per plant, and number of eggs/egg mass as well as improve of the different vegetative eggplant growth parameters. Among all tested agents $B$. subtilis performance was the best for enhancing plant growth characters and suppressing the RKN infection. Also, data in Table 1 demonstrated that soil treated with B. subtilis simultaneously and after 1 month from $M$. incognita egg inoculation resulted in announced low number in $\mathrm{J}_{2}$ in soil as $91 \mathrm{~J}_{2} / \mathrm{kg}$ soil followed by chitosan, A. chroococcum, and A. brasilense which recorded 119,140 , and $210 \mathrm{~J}_{2} / \mathrm{kg}$, respectively. Also, treated soil simultaneously with egg inoculation revealed moderate rate counts of $\mathrm{J}_{2}$ in roots recorded as 29 $\mathrm{J}_{2}$ in $5 \mathrm{~g}$ roots at $B$. subtilis application, followed by 48,48 , and $53 \mathrm{~J}_{2} /$ in $5 \mathrm{~g}$ roots at applied treatments of $\mathrm{A}$. brasilense, chitosan, and $A$. chroococcum, in respective order.

Illustrated data in Fig. 1 showed that at soil treated with chitosan 3 days before $M$. incognita eggs inoculation was recorded, a reduction in root galls by $81.4 \%$, followed by $77.7,62.9$, and $22.2 \%$ at the treatments of $A$. brasilense, $B$. subtilis, and $A$. chroococcum, respectively. The most prominent effect in reducing egg mass was $B$. subtilis when applied simultaneously plus 1 month after the first treatment recording $95.4 \%$ over control, followed by 90.9 and 40.9 with chitosan and A. chroococcum, respectively. Meanwhile, the least effect was calculated (18.2\%) and was found at A. brasilense treatment over control treatment. Obtained results are in agreement with those of Tian et al. (2007) and Lugtenberg and Kamilova (2009) who reported that the living bacteria in plant rhizosphere (rhizobacteria) are mostly plentiful microorganisms that revealing different modes of action against nematodes, which include production of several antibiotics, enzymes, and toxins; in addition, they can also elevate systemic resistance of plants against nematodes. The present investigation showed that $B$. subtilis was the most prominent bacteria in reducing nematodes population. In a harmony of these results, Kavitha et al. (2012) and Engelbrecht et al. (2018) recorded substantial impact of Bacillus spp. as biocontrol agents on plant-parasitic nematodes. Under stressed conditions, these strains have multiple modes of action and a promising ability to sporulate. Furthermore, $B$. subtilis produce cyclic lipopeptides of surfactin and iturin which inhibit egg hatching of M. incognita and play an imperative role in increasing the percentage of juvenile mortality (El-Hadrami et al. 2010). In addition, a direct antagonism was also reported by Bacillus sp. against several plant-parasitic nematodes, i.e., Meloidogyne, Heterodera, and Rotylenchulus (Kokalis-Burelle et al. 2002, and Li et al. 2005). Also, the present study revealed more effectively of $A$. brasilense for reducing nematode population when applied 3 days before eggs inoculum that was referred to its role as resistance elicitors, which leads to the accumulation of phytoalexin suppress nematode viability (Bashan 1998). Also, plant growth-promoting rhizobacteria strains, e.g., Psudomonas fluorescens, Azotobacter chroococcum, and Azospirillum brasilense inhibited egg hatching and killed

Table 1 Effect of growth-promoting bacteria and chitosan on development and multiplication of root-knot nematode Meloidogyne incognita

\begin{tabular}{|c|c|c|c|c|c|c|}
\hline \multirow[t]{2}{*}{ Treatment } & \multirow{2}{*}{$\begin{array}{l}\text { Application } \\
\text { time }\end{array}$} & \multicolumn{5}{|c|}{ Measured parameters } \\
\hline & & No. of $J_{2} / \mathrm{kg}$ soil & No. of $\mathrm{J}_{2} / 5 \mathrm{~g}$ roots & No. of galls & No. of egg masses & No. of eggs/egg mass \\
\hline \multirow[t]{3}{*}{ Azospirilum brasilense } & A & $336 \mathrm{~b}$ & $48 c$ & $120 \mathrm{~b}$ & $83 b$ & $427 b$ \\
\hline & B & $210 d$ & $90 \mathrm{~b}$ & $115 b$ & $90 \mathrm{~b}$ & $403 d$ \\
\hline & C & $105 \mathrm{fg}$ & $45 c$ & $30 \mathrm{gh}$ & 10 ef & $339 \mathrm{~g}$ \\
\hline \multirow[t]{3}{*}{ Azotobacter chroococcum } & A & $214 d$ & $53 c$ & $35 \mathrm{fg}$ & 10 ef & $312 \mathrm{~h}$ \\
\hline & B & $140 \mathrm{e}$ & $40 \mathrm{~cd}$ & $90 \mathrm{~d}$ & $65 c$ & 387 e \\
\hline & C & $109 \mathrm{f}$ & $45 c$ & $105 \mathrm{c}$ & $85 b$ & 378 e \\
\hline \multirow[t]{3}{*}{ Bacillus subtilis } & $A$ & $231 \mathrm{c}$ & $29 d$ & 45 ef & $15 \mathrm{e}$ & $423 \mathrm{bc}$ \\
\hline & B & $91 \mathrm{~g}$ & $45 c$ & 40 ef & 10 ef & $320 \mathrm{~h}$ \\
\hline & C & $115 f$ & $42 \mathrm{c}$ & $25 \mathrm{~h}$ & 10 ef & $409 \mathrm{~cd}$ \\
\hline \multirow[t]{3}{*}{ Chitosan } & A & $240 \mathrm{c}$ & $76.8 \mathrm{~b}$ & $115 b c$ & $40 d$ & $361 \mathrm{f}$ \\
\hline & B & $119 f$ & $88.4 \mathrm{~b}$ & $30 \mathrm{gh}$ & $5 f$ & $344 \mathrm{~g}$ \\
\hline & C & $210 d$ & 79.7 b & 50 e & $40 d$ & $320 \mathrm{~h}$ \\
\hline Untreated control & & $1035 \mathrm{a}$ & $186 a$ & $135 \mathrm{a}$ & $110 \mathrm{a}$ & $458 \mathrm{a}$ \\
\hline
\end{tabular}


Table 2 Effect of growth-promoting bacteria and chitosan on plant morphogenesis of eggplants infected with root-knot nematode Meloidogyne incognita

\begin{tabular}{|c|c|c|c|c|c|c|}
\hline \multirow[t]{3}{*}{ Treatments } & \multirow{3}{*}{$\begin{array}{l}\text { Time of } \\
\text { application }\end{array}$} & \multicolumn{5}{|c|}{ Plant morphogenesis } \\
\hline & & \multicolumn{2}{|c|}{ Plant height $(\mathrm{cm})$} & \multicolumn{2}{|c|}{ Shoot system weight (g) } & \multirow{2}{*}{$\begin{array}{l}\text { Nos. } \\
\text { of } \\
\text { leaves }\end{array}$} \\
\hline & & Shoot & Root & Fresh & Dry & \\
\hline \multirow[t]{3}{*}{ Azospirilum brasilense } & A & 24 de & $12.5 \mathrm{~cd}$ & $40 \mathrm{~g}$ & $8 \mathrm{~cd}$ & $6 d$ \\
\hline & B & $29 a b$ & $14 b c$ & $44 \mathrm{fg}$ & $10 \mathrm{bc}$ & $7 \mathrm{~cd}$ \\
\hline & C & $27 \mathrm{bc}$ & $15 a b$ & $46 f$ & $8 \mathrm{~cd}$ & $7 \mathrm{~cd}$ \\
\hline \multirow[t]{3}{*}{ Azotobacter chroococcum } & A & $31.5 \mathrm{ab}$ & $17 \mathrm{a}$ & 56 e & $8 \mathrm{~cd}$ & $7 \mathrm{~cd}$ \\
\hline & B & $33 a$ & $16 \mathrm{ab}$ & $78 \mathrm{~b}$ & $10 \mathrm{bc}$ & $9 \mathrm{bc}$ \\
\hline & C & $25.5 \mathrm{~cd}$ & $15 \mathrm{ab}$ & 54 e & $8 \mathrm{~cd}$ & 13 a \\
\hline \multirow[t]{3}{*}{ Bacillus subtilis } & A & 33 a & $16 \mathrm{ab}$ & $64 d$ & $10 \mathrm{bc}$ & $9 \mathrm{bc}$ \\
\hline & B & 33 a & $14 b c$ & $70 \mathrm{c}$ & $12 a b$ & $11 a b$ \\
\hline & C & $31 \mathrm{ab}$ & $13 \mathrm{~cd}$ & $98 \mathrm{a}$ & $14 \mathrm{a}$ & $12 \mathrm{a}$ \\
\hline \multirow[t]{3}{*}{ Chitosan } & A & 25 de & $12 \mathrm{~cd}$ & $48 \mathrm{f}$ & $12 a b$ & $6 d$ \\
\hline & B & $27 \mathrm{bc}$ & $11 \mathrm{de}$ & $48 \mathrm{f}$ & $10 \mathrm{bc}$ & $6 d$ \\
\hline & C & $25.5 \mathrm{~cd}$ & $12 \mathrm{~cd}$ & $48 \mathrm{f}$ & $13 a$ & $9 \mathrm{bc}$ \\
\hline Control & & $15 \mathrm{e}$ & $9 \mathrm{e}$ & $29 \mathrm{~h}$ & $7 d$ & $5 d$ \\
\hline
\end{tabular}

$A$ simultaneously, $B$ simultaneously and after 1 month, $C 3$ days before eggs

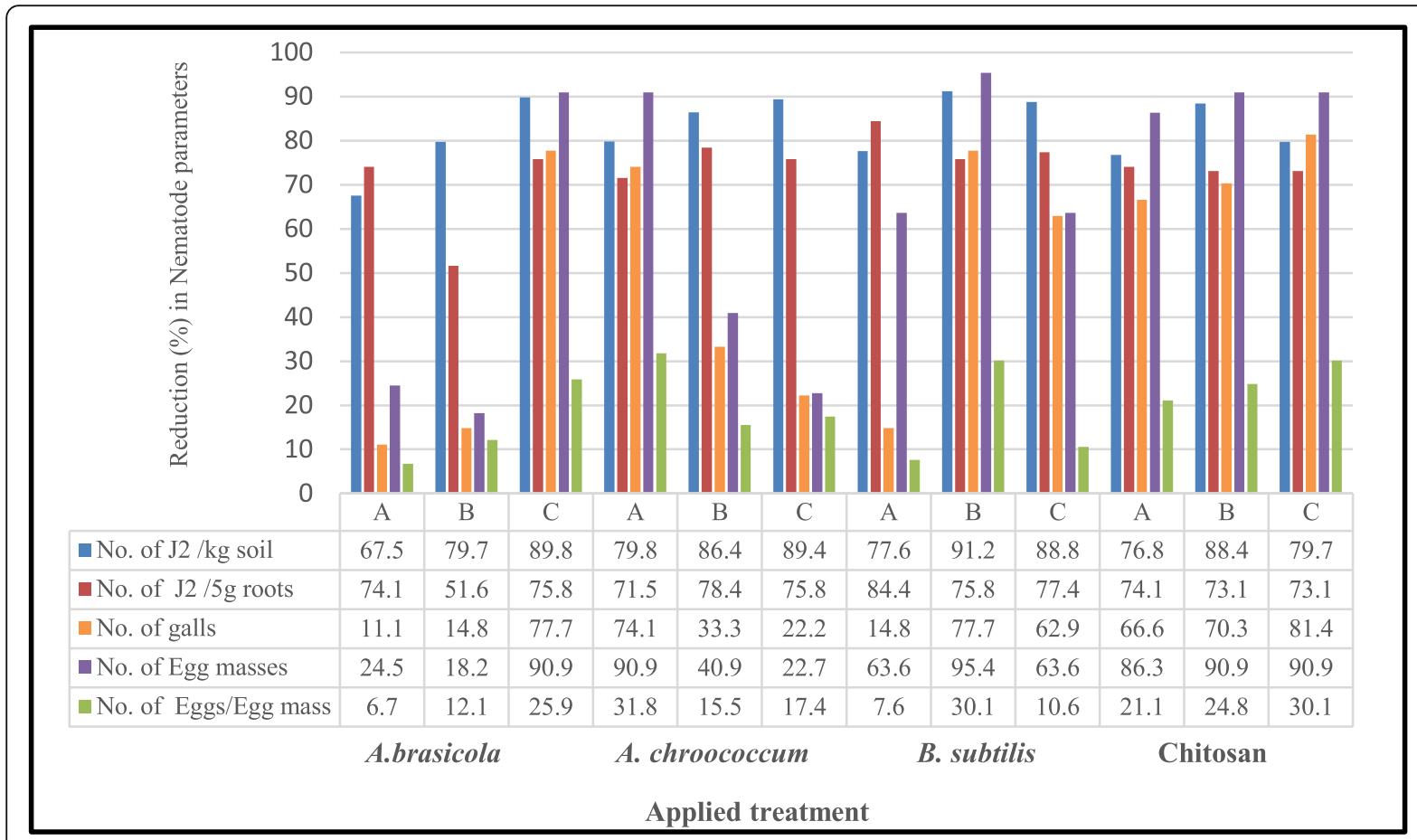

Whereas $\mathrm{A}=$ Simultaneously; $\mathrm{B}=$ Simultaneouslyand after one month; $\mathrm{C}=$ Three days before eggs

Fig. 1 Reduction (\%) in development and multiplication of root-knot nematode Meloidogyne incognita in response to growth-promoting bacteria and chitosan. A, simultaneously; B, simultaneously and after 1 month; C,3 days before eggs 


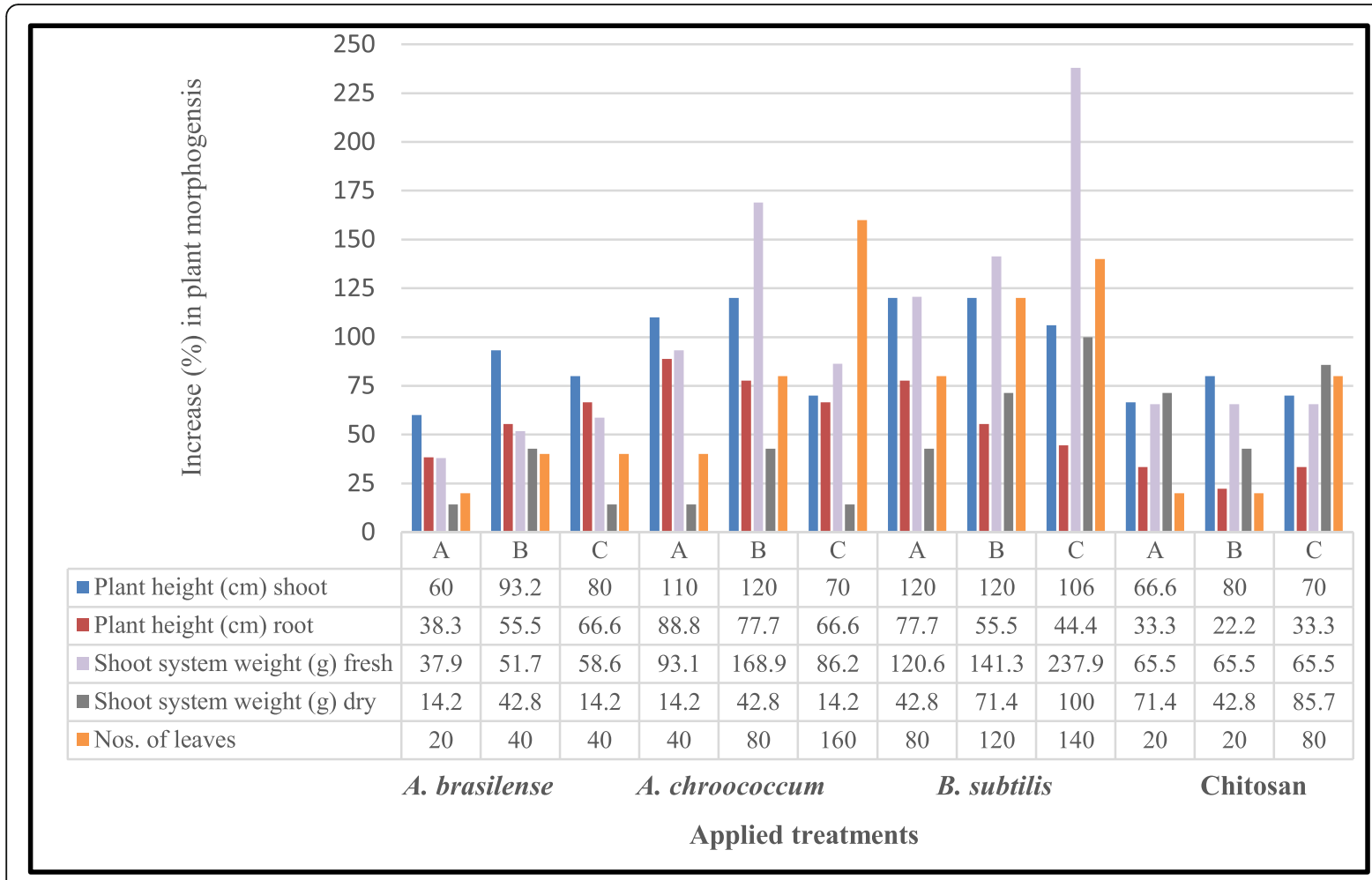

Whereas $\mathrm{A}=$ Simultaneously; $\mathrm{B}=$ Simultaneously and after one month; $\mathrm{C}=$ Three days before eggs

Fig. 2 Increasing (\%) in morphogenesis of infected eggplant with root-knot nematode Meloidogyne incognita in response to promoting bacteria and chitosan. A, simultaneously; B, simultaneously and after 1 month; C, 3 days before eggs

juveniles by producing a wide variety of antibiotics, sidrophores, hydrolytic enzymes, organic compounds, $\mathrm{HCN}$, phenol oxidation, and protease (Insunza et al. 2002, and Siddiqui et al. 2005). On the other hand, Chitosan is one of the auspicious agents utilized against plant pathogens as it displays a wide range of antimicrobial activities and shows a hypersensitive response to pathogens infection (Kulikov et al. 2006). Chitosan have revealed antiviral, antibacterial, and antifungal effects and have been suggested for many agricultural uses. Also, it has been utilized for controlling disease or reducing their development and enhancing plant inherent defenses (El-Hadrami et al. 2010). Obtained results of chitosan on $M$. incognita reproduction and eggplant growth in agreement with those of Khalil and Badawy (2012) who demonstrated that chitosan decrease the severity of root-knot disease by inducing physiological alterations in both nematodes and plants that prevent successful reproduction of the nematodes and supply local and systemic resistance (Aboud et al. 2002). Likewise, exhibition elicitor activity by chitosan has been reported through induction of local and systemic resistance mechanisms of tomato plants against $M$. incognita (Radwan et al. 2012).

\section{Effect of different treatments on vegetative eggplant growth parameters}

Results presented in Table 2 demonstrated different significant $(P \leq 0.05)$ stimulatory effects of the evaluated agents on vegetative eggplant growth parameters in terms of shoot, root lengths, fresh, dry shoot weights, and numbers of leaves relative to different times of application. The highest percent increase in plant height $33.0 \mathrm{~cm}$ was achieved by the application of $B$. subtilis simultaneously and simultaneously plus 1 month later, while adding $B$. subtilis 3 days before inoculation resulted in $98 \mathrm{~g}$ and $14 \mathrm{~g}$ fresh and dry shoot weights and the numbers of leaves calculated as 12 , in relevant respective order. Treatments of $A$. chroococcum ranked second for enhancing eggplant growth parameters than the control, followed by $A$. brasilense and chitosan (Table 2).

Moreover, illustrated data in Fig. 2 revealed the highest calculated increase over control treatment in plant height shoot and root length as 120, 77.7 and 237.9, 100, $140.0 \%$ for fresh, weights of shoot system, and numbers of leaves at B. subtilis either applied as simultaneously and 3 days before inoculation treatments, in relevant respective order. The significant effects on eggplant 
growth given by the rhizobacteria would mainly be due to the increase in root length which in turn increases the mineral uptake in plants, and the production and regulation of phyto-hormones lead to increase of biomass; moreover, these bacteria survive in soil around plants and can provide growth promotion materials and furthermore suppression of disease-causing organisms (Tian et al. 2007; Lugtenberg and Kamilova 2009). Also, Morsy et al. (2009) and Soliman et al. (2011) stated that $A$. chroococcum and A. brasilense improve plant growth parameters as well as chemical components by the production of growth hormones (IAA, gibberellins, and auxins) or by converting unavailable minerals and organic compounds into forms available to plants. Furthermore, Morgenstern and Okon (1987) found that $A$. brasilense increased root hair formation and produced more lateral roots which lead to increase the nutrient uptake and improve plant growth.

In the present investigation, the positive effect on eggplant growth parameters was recorded by chitosan. These results are in agreement with Khalil and Badawy (2012) and El-Sayed and Mahdy (2014-15) who revealed that the capability of chitosan to stimulate and manufacture defense compounds and modulate the soil's biological and physical properties which improve plant growth parameters, i.e., root and shoot length and weights compared to the plants treated with nematode alone. Likewise, Ashif et al. (2017) reported the affectivity of chitosan applied to maximize reduction in egg mass/root, eggs/egg mass, nematode population, and root-knot indices in cultivated eggplant compared to the control. They added that application of chitosan increased plant growth, i.e., plant length, fresh and dry weights, pollen fertility, and yield as well as some biochemical parameters such as chlorophyll, carotenoid content, and antioxidant enzymes. They conclude that the eliciting activity of chitosan and activating systemic resistance in the plant as well as during decomposition it release different toxic chemical compounds which have fatal effects against $\mathrm{J}_{2}$ and multiplication of the RKN, $M$. incognita.

\section{Conclusion}

The results concluded that using the plant growthpromoting rhizobacteria, A. brasilense, A. chroococcum, B. subtilis, and chitosan achieved efficient control to the RKN, M. incognita with consequent increase in eggplant growth under greenhouse conditions. Such approach could be generally used successfully for controlling plant-parasitic nematode affecting economic crops.

\section{Abbreviations}

$\mathrm{J}_{2}$ : Second-stage juvenile; IAA: Indole acetic acid; RKN: Root-knot nematode; A: Simultaneously; B: Simultaneously and after one month; C: Three days before eggs

\section{Acknowledgements}

The authors are grateful to Dr. Hoda Hussein Ameen, Department of Plant Pathology, National Research Centre, Egypt, for her guidance throughout this work and manuscript revision.

\section{Authors' contributions}

MA suggested the aim of study, designed the experimental work, and wrote and revised the manuscript. NE shared in the experimental design, prepared the bioagents cultures and performed the statistical analysis of the collected data. UE shared in the experimental design, performed, followed the greenhouse work, carried out all the nematode investigations, and collected and tabulated data. All authors read and approved the final manuscript.

\section{Funding}

This work was supported in part with the In-House Project No. 11030132 of the National Research Center, Giza, Egypt. This support includes greenhouse, pots, eggplant transplants, and chemical used.

\section{Availability of data and materials}

The datasets used and/or analyzed during the current study are available from the authors on reasonable request.

Ethics approval and consent to participate

Not applicable

\section{Consent for publication}

Not applicable

\section{Competing interests}

The authors declare that there are no competing interests.

Received: 15 June 2020 Accepted: 21 October 2020

Published online: 04 November 2020

\section{References}

Abdel-Kader MM, El-Mougy NS, Aly MDE, Lashin SM (2012) Long activity of stored formulated bio-agents against some soil-borne plant pathogenic fungi causing root rot of some vegetables. J Appl Sci Res 8(4):1882-1892 http:/www.aensiweb.com/old/jasr/jasr/2012/1882-1892.pdf

Aboud HM, Fattah FA, Al-Heeti AA, Saleh HM (2002) Efficiency of chitosan in inducing systemic acquired resistance against the root-knot nematode (Meloidogyne javanica (Treub) Chitwood) on tomato. Arab J Plant Prot 20:9398

Asif M, Ahmad F, Tariq M, Khan A, Ansari T, Khan F, Siddiqui AM (2017) Potential of chitosan alone and in combination with agricultural wastes against the root-knot nematode, Meloidogyne incognita infesting eggplant. J Plant Prot Res 57(3):1-8.

Bashan Y (1998) Azospirillum plant growth-promoting strains are nonpathogenic on tomato, pepper, cotton. and wheat. Can J Microbiol 44:168-174. https:// doi.org/10.1139/cjm-44-2-168

Duncan DB (1955) Multiple ranges and multiple F. test. Biometrics 11:11-24

El-Hadrami A, Lorne RA, El-Hadrami I, Daayf F (2010) Chitosan in plant protection. Mar. Drugs 8:968-987. https://doi.org/10.3390/md8040968

El-Sayed SM, Mahdy ME (2014-2015) Effect of chitosan on root-knot nematode, Meloidogyne javanica on tomato plants. Int J Chem Tech Res. 7 (4):1985-1992. https://pdfs.semanticscholar.org/e0a5/1cec6d80c77a1f80d9112412f432fdf645 e4.pdf

Engelbrecht G, Horak I, Peet J, van Rensburg J, Claassens S (2018) Bacillus-based bionematicides: development, modes of action and commercialization. Biocon Sci Technol 28(7):629-653. https://doi.org/10.1080/09583157.2018. 1469000

Holbrook CC, Knauft DA, Dikson DW (1983) A technique for screening peanut for resistance to Meloidogyne arenaria. Plant Dis 57:957-958 https://www.apsnet. org/publications/PlantDisease/Backlssues/Documents/1983Articles/ PlantDisease67n09_957.PDF

Hussey RS, Barker KR (1973) A comparison of methods collecting inocula of Meloidogyne spp. including a new technique. Plant Dis Repter 57:1025-1028

Insunza V, Alstrom S, Eriksson KB (2002) Root bacteria from nematicidal plants and their biocontrol potential against trichodorid nematodes in potato. Plant Soil 241:271-278. https://doi.org/10.1023/A:1016159902759 
Kavitha PG, Jonathan El, Nakkeeran S (2012) Effects of crude antibiotic of Bacillus subtilis on hatching of eggs and mortality of juveniles of Meloidogyne incognita. Nematol Medit 40:203-206 https://journals.flvc.org/nemamedi/ article/view/87105

Khalil MS, Badawy ME (2012) Nematicidal activity of a biopolymer chitosan at different molecular weights against root-knot nematode, Meloidogyne incognita. Plant Prot Sci 48:170-178. https://doi.org/10.17221/46/2011-PPS

Khan Z, Kim SG, Jeon YH, Kh HU, Son SH, Kim YH (2008) A plant growth promoting rhizobacterium, Paenibacillus polymyxa strain GBR-1, suppresses root-knot nematode. Bioresour Technol 99:3016-3023. https://doi.org/10. 1016/j.biortech.2007.06.031

Kokalis-Burelle N, Vavrina CS, Rosskopf EN, Shelby RA (2002) Field evaluation of plant growth-promoting rhizobacteria amended transplant mixes and soil solarization for tomato and pepper production in Florida. Plant Soil 238:257266 https://link.springer.com/article/10.1023/A:1014464716261

Kulikov SN, Chirkov SN, I'ina AV, Lopatin SA, Varlamov VP (2006) Effect of the molecular weight of chitosan on its antiviral activity in plants. Prik. Biokhim. Mikrobiol. 42(2):224-228. https://doi.org/10.1134/S0003683806020165

Li B, Xie GL, Soad A, Coosemans J (2005) Suppression of Meloidogyne javanica by antagonistic and plant growth promoting rhizobacteria. J Zhejiang Univ Sci B. 6, 496-501. Doi: https://doi.org/10.1631/jzus.2005.B0496

Lugtenberg B, Kamilova F (2009) Plant growth promoting rhizobacteria. Annu Rev Microbiol 63:541-556 https://www.annualreviews.org/doi/abs/10.1146/ annurev.micro.62.081307.162918

Morgenstern E, Okon Y (1987) The effect of Azospirillum brasilense and auxin on root morphology in seedlings of Sorghum bicolor X Sorghum sudanense. Arid Soil. Res. Rehabil. 1:115-127 https://www.tandfonline.com/doi/abs/10.1 080/15324988709381135

Morsy EM, El-Batanony NH, Massoud ON (2009) Improvement of Sorghum bicolor L. growth and yield in response to Azotobacter chroococcum, compost water extracts and Arbascular mycorrhiza fungi: different application methods. New Egypt J Microbiol 23:127-144

Oka Y, Kolta H, Bar-Eyal M, Mor M, Sharon E, Chet I, Spiegel Y (2000) New strategies for the control of plant-parasitic nematodes. Pest Manag Sci 56: 983-988 10.1002/1526-4998(200011)56:11<983:.AID-PS233>3.0.CO;2-X

Radwan MA, Farrag SAA, Abu-Elamayem MM, Ahmed NS (2012) Extraction, characterization, and nematicidal activity of chitin and chitosan derived from shrimp shell wastes. Biology and Fertility of Soils 48(4):463-468. https://doi. org/10.1007/s00374-011-0632-7

Siddiqui IA, Haas D, Heeb S (2005) Extracellular Protease of Pseudomonas fluorescens $\mathrm{CHA0}$, a biocontrol 5649 factor with activity against the root-knot nematode Meloidogyne incognita. Appl. Environ. Microbiol. 71:5646-5649. https://doi.org/10.1128/AEM.71.9.5646-5649.2005

Soliman AS, Shawky SM, Omar NMA (2011) Efficiency of bioagents in controlling root-knot nematode on acacia plants in Egypt. American-Eurasian J. Agric. Environ. Sci. 10(2):223-229 http://idosi.org/aejaes/jaes10(2)/15.pdf

Talavera M, Sayadi S, Chirosa-Ríos M, Salmerón T, Flor-Peregrín E, Verdejo-Lucas S (2012) Perception of the impact of root-knot nematodeinduced diseases in horticultural protected crops of south-eastern Spain. Nematology 14:517527. https://doi.org/10.1163/156854112X635850

Taylor AL, Sasser JN (1978) Biology, identification and control of root-knot nematodes, Meloidogyne spp. International Meloidogyne Project Publication. North Carolina State Graphics Univ, Raleigh, p 111

Tian B, Yang J, Zhang KQ (2007) Bacteria used in the biological control of plant parasitic nematodes: population, mechanisms of action and future prospects. FEMS Microbiol Ecol 61:197-213. https://doi.org/10.1111/j.1574-6941.2007. 00349.x

\section{Publisher's Note}

Springer Nature remains neutral with regard to jurisdictional claims in published maps and institutional affiliations.

\section{Submit your manuscript to a SpringerOpen ${ }^{\odot}$ journal and benefit from:}

- Convenient online submission

- Rigorous peer review

- Open access: articles freely available online

- High visibility within the field

- Retaining the copyright to your article

Submit your next manuscript at $\boldsymbol{\sim}$ springeropen.com 